\title{
Prevention of in Vivo Excitotoxicity by a Family of Trialkylglycines, a Novel Class of Neuroprotectants
}

\author{
CARMINA MONTOLIU, MARC HUMET, JUAN-JOSÉ CANALES, JOZEF BURDA, ROSA PLANELLS-CASES, \\ FRANCISCO SÁNCHEZ-BAEZA, TERESA CARBONELL, ENRIQUE PÉREZ-PAYÁ, ANGEL MESSEGUER, \\ ANTONIO FERRER-MONTIEL, and VICENTE FELIPO \\ Laboratory of Neurobiology, Instituto de Investigaciones Citológicas, Fundación Valenciana de investigaciones Biomedicas, Valencia, Spain \\ (C.M., J.-J.C., J.B., V.F.); Institut d'Investigacions Químiques i Ambientals de Barcelona, Consejo Superior de Investigaciones Cientificas, \\ Barcelona, Spain (M.H., F.S.-B., A.M.); Centro de Biología Molecular y Celular, Universidad Miguel Hernández, Alicante, Spain (R.P.-C., \\ A.F.-M.); and Departamento de Bioquímica y Biología Molecular, Universidad de Valencia, Valencia, Spain (T.C., E.P.-P.)
}

Received September 10, 2001; accepted December 13, $2001 \quad$ This article is available online at http://jpet.aspetjournals.org

\begin{abstract}
Excitotoxicity has been implicated in the etiology of ischemic stroke and chronic neurodegenerative disorders. Hence, the development of novel neuroprotectant molecules that ameliorate excitotoxic brain damage is vigorously pursued. We used a neuroprotection-based cellular assay to screen a synthetic combinatorial library of $N$-alkylglycine trimers. Two compounds (6-1-2 and 6-1-10) that efficiently prevented excitotoxic neurodegeneration in vitro and in vivo were identified. Both molecules protected primary cultures of cerebellar neurons against glutamate-induced neuronal death with an efficiency equivalent to $N$-methyl-D-aspartate (NMDA) receptor antagonists. These trialkylglycines did not block appreciably the NMDA receptor channel, or attenuated glutamate-induced increase of $\mathrm{Ca}^{2+}$, or affect the glutamate-nitric oxide-cGMP pathway. Intraperito-
\end{abstract}

neal injection of both peptoids in mice attenuated $\geq 80 \%$ ammonia-induced, NMDA receptor-mediated animal death. Furthermore, these two molecules reduced by $\geq 50 \%$ the neurodegeneration in striatum in a rat model of cerebral ischemia. Neuroprotection against ischemia was associated with decreased activation of caspase-3, reflecting prevention of apoptotic neuronal death. Collectively, the results reported indicate that these trialkylglycines are new neuroprotectant leads with important in vivo activity against excitotoxicity, and that they act on a novel, yet-unrecognized cellular target. These lead compounds may become tolerated drugs for the treatment of acute and chronic neurodegenerative diseases with fewer side effects than NMDA receptor antagonists.
Glutamate is considered the main excitatory neurotransmitter in mammals. However, excessive activation of glutamate receptors, particularly of the NMDA receptor subtype, leads to neuronal degeneration and death (Choi and Rothman, 1990). Glutamate neurotoxicity is involved in the neuronal damage found in cerebral ischemia, as well as in the pathogenesis of different neurodegenerative diseases, including amyotrophic lateral sclerosis, and Huntington, Alzheimer, and Parkinson diseases (Choi and Rothman, 1990; Kroemer et al., 1998). Although the underlying mechanisms for the selective vulnerability of neurons are unknown, a widely held view considers that excessive activation of NMDA re-

This study was supported in part by grants from Fundació La Marató de TV3 (to V.F and A.M); Grants PM98-0065, PM99-0018, and SAF97-0001 of the Ministerio de Educación y Ciencia and of Plan Nacional de I + D of Spain (to V.F.); grants from the Comisión Interministerial de Ciencia y Tecnología and the European Commission (1FD97-0662-C02-01) (to A.F.-M. and E.P.-P.) and La Fundación La Caixa (98/027-00) (to A.F.-M.); and from Comisión Interministerial de Ciencia y Tecnología (SAF98-0059) (to A.M.). J.J.-C. has a Contrato de Reincorporación of the Ministerio de Educación, Cultura y Deporte of Spain. ceptor mediates a massive influx of $\mathrm{Ca}^{2+}$, which induces different effects, including alterations of the mitochondrial potential and formation of nitric oxide and cGMP. These alterations lead ultimately to cell death (Choi, 1987; Dawson et al., 1991; Dawson et al., 1993; Mattson et al., 1993; Montoliu et al., 1999).

Because of their central role in neurodegeneration, NMDA receptors have been considered prime therapeutic targets for the development of useful neuroprotective strategies (Bräuner-Osborne et al., 2000). Accordingly, a significant effort has been made to develop high-affinity and selective NMDA antagonists that target the different drug binding sites on this receptor. Although most of these molecules efficiently reduce glutamate neurotoxicity in vitro, their in vivo utility has been heavily questioned due to serious side effects at clinically effective doses (Choi and Rothman, 1990; Morris and Davis, 1995; Bräuner-Osborne et al., 2000). The high receptor affinity of known NMDA receptor antagonists appears to be a major shortcoming because these compounds 
bind to both pathologically activated and physiologically working NMDA receptor populations (Choi and Rothman, 1990; Kroemer et al., 1998). Because NMDA receptors are implicated in learning and memory, inhibition of glutamatergic neurotransmission may underlie the cognitive deficits provoked by high-affinity NMDA receptor antagonists (Morris and Davis, 1995). In addition, it has been reported that chronic administration of these antagonists enhances neuronal death (Ikonomidou et al., 2000; Olney et al., 2000). Therapeutic alternatives that may significantly overcome these deficiencies involve the use of uncompetitive NMDA antagonists (Lipton and Rosenburg, 1994; Ferrer-Montiel et al., 1998), NMDA receptor subtype-specific blockers (Chenard and Menniti, 1999; Bräuner-Osborne et al., 2000), or NMDA receptor-directed oral vaccines (During et al., 2000).

Alternatively, molecules that prevent neuronal death by acting on other cellular targets involved in neurodegeneration onset may be therapeutically useful to ameliorate the harmful consequences of excitotoxicity. These compounds may be devoid of the adverse in vivo effects of well established NMDA antagonists. To address this issue, we have used a neuroprotection-based cellular assay to identify neuroprotectant molecules from a combinatorial library of oligo $N$-substituted glycines (Fig. 1). At variance with biological assays that focus on receptor activity, we have evaluated the efficiency of combinatorial mixtures preventing glutamateinduced neuronal death directly on primary cultures of cerebellar neurons. Library deconvolution identified a family of trialkylglycines that efficiently reduced excitotoxic cell death in cultured neurons (Fig. 2). Noteworthy, intraperitoneal administration of compounds $N$-[2-( $N$-pyrrolidinyl)ethyl]glycyl]-[ $N$-[cyclopropyl]glycyl]- $N$-(sec-butyl)glycinamide (referred to as 6-1-2) and [N-[2-( $N$-pyrrolidinyl)ethyl]glycyl]-[N[cyclopropyl]glycyl]- $N$-(2-phenethyl)glycinamide (denoted as 6-1-10) significantly protected mice against ammoniainduced, NMDA receptor-mediated animal death. In addition, these two peptoids remarkably prevented the neuronal apoptosis induced by cerebral ischemia in rats. Both compounds are novel neuroprotectants that act on an as yetunrecognized cellular target. Because these neuroprotectant peptoids do not block the NMDA receptor, the psychotropic effects displayed by antagonists of this ionotropic receptor may be avoided.

\section{Experimental Procedures}

\section{Materials}

Basal Eagle's medium, fetal bovine serum, and gentamycin were from Invitrogen (Rockville, MD). DNase I (E.C. 3.1.21.1) and dispase II were from Roche Applied Science (Mannheim, Germany). Glutamate and NMDA were from Sigma Chemical (St. Louis, MO). Fluorescein diacetate, propidium iodide, and fluo-3/AM were from Molecular Probes (Leuven, Belgium). Culture plates were from Costar (Cambridge, MA). The kit for cGMP determination was from Amersham plc (Little Chalfont, Buckinghamshire, UK).

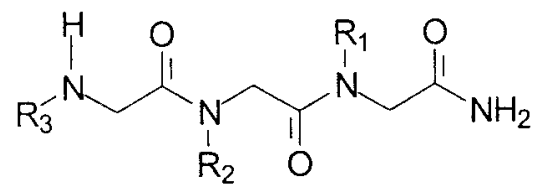

Fig. 1. Chemical structure of the library of $N$-alkylglycine trimers.

\section{Synthesis of Library of $\mathbf{N}$-Alkylglycines}

A library of 10,648 compounds in 66 controlled mixtures was synthesized by using the positional scanning format in solid phase (Pinilla et al., 1992; Figliozzi et al., 1996). In our case, a collection of 22 commercially available primary amines was used for introducing the desired chemical diversity in the library. The details of this synthesis will be described elsewhere (M. Humet, T. Carbonell, F. Sánchez-Baeza, P. Mora, E. Cantón, M. Bobernado, E. Percz-Paya, and A. Messeguer, manuscript in preparation). Briefly, starting from Rink amide resin (Rapp Polymere, $0.7 \mathrm{meq}$ ) the eight-step synthetic pathway involved the initial release of the Fmoc protecting group. Then the successive steps of acylation with chloroacetyl chloride followed by the corresponding amination of the chloromethyl intermediate using the particular primary amine, or the equimolecular mixture of the 22 amines was conducted as appropriate. All these reactions were carried out in duplicate. Finally, the products were released from the resin by using a trifluoroacetic acid/dichloromethane/water mixture, solvents were evaporated, and the residues were lyophilized and dissolved in $10 \%$ dimethyl sulfoxide at the concentration of $10 \mathrm{mg} / \mathrm{ml}$ for screening of neuroprotection.

\section{Synthesis of Individual Neuroprotective Trialkylglycines}

The results from the screening of the 66 mixtures of the peptoid library led to a deconvolution process from which the synthesis of 12 individual molecules was derived. These trialkylglycines were prepared on solid phase following the same synthetic scheme but using the $N$-hydroxysuccinimide ester of chlorocaetic acid as acylating agent and the appropriate amines for the amination steps. The screening of these library members in the in vitro test led to the final selection of two trimers (612 and 6110; Fig. 2) as the most active candidates for performing the in vivo assays. Crude compounds 612 and $\mathbf{6 1 1 0}$ obtained from the release of the resin were purified by preparative reversed phase high-performance liquid chromatography using a $250-\times 20$-mm column packed with $5-\mu \mathrm{m}$ Kromasil C-8. Methanol and water, both containing $0.1 \%$ trifluoroacetic acid, were used as a mobile phases at $6 \mathrm{ml} / \mathrm{min}$, under the following elution conditions: 20:80 methanol/water during 2 min and then gradient up to $100 \%$ methanol in $30 \mathrm{~min}$. Eluates were collected, methanol was removed under vacuum, and the residues were lyophilized to render the desired compounds ( $>95 \%$ purity by high-performance liquid chromatography).

612. ${ }^{1} \mathrm{H}$-NMR (500 $\mathrm{MHz}, 10^{\circ} \mathrm{C}$ in $\mathrm{D}_{2} \mathrm{O}$, mixture of conformers), $\delta$ from N-terminal to C-terminal: $2.04-1.89\left(\mathrm{~m}, 4 \mathrm{H}, \mathrm{CH}_{2} \mathrm{CH}_{2} \mathrm{~N}\right.$ pyrrolidine), 3.01-3.61 (m, $4 \mathrm{H}, \quad \mathrm{CH}_{2} \mathrm{~N}$ pyrrolidine), $3.52(\mathrm{t}, 2 \mathrm{H}$, $\mathrm{CH}_{2} \mathrm{CH}_{2} \mathrm{NH}$ ), 3.45 (t, $\left.2 \mathrm{H}, \mathrm{CH}_{2} \mathrm{NH}\right), 4.31\left(\mathrm{~s}, 2 \mathrm{H}, \mathrm{CH}_{2} \mathrm{CO}\right), 2.73(\mathrm{~m}, 1 \mathrm{H}$, $\mathrm{CHN}), 0.69-0.80\left(\mathrm{~m}, 4 \mathrm{H},\left(\mathrm{CH}_{2}\right)_{2} \mathrm{CHN}\right), 4.35\left(\mathrm{~s}, 2 \mathrm{H}, \mathrm{CH}_{2} \mathrm{CO}\right), 3.73(\mathrm{~m}$, $\left.1 \mathrm{H}, \mathrm{CH}_{3} \mathrm{CHCH}_{2} \mathrm{CH}_{3}\right), 1.43\left(\mathrm{~m}, 2 \mathrm{H}, \mathrm{CH}_{3} \mathrm{CHCH}_{2} \mathrm{CH}_{3}\right), 0.76(\mathrm{~m}, 3 \mathrm{H}$, $\mathrm{CH}_{3} \mathrm{CHCH}_{2} \mathrm{CH}_{3}$ ), 1.07 (m, 3H, $\mathrm{CH}_{3} \mathrm{CHCH}_{2} \mathrm{CH}_{3}$ ), 3.72-3.89 (m, 2H, $\mathrm{CH}_{2} \mathrm{CO}$ ). ${ }^{13} \mathrm{C}-\mathrm{NMR}\left(500 \mathrm{MHz}, 10^{\circ} \mathrm{C}\right.$ in $\left.\mathrm{D}_{2} 0\right), \delta$ from $\mathrm{N}$-terminal to C-terminal: $24.8\left(\mathrm{CH}_{2} \mathrm{CH}_{2} \mathrm{~N}\right.$ pyrrolidine $), 57.2\left(\mathrm{CH}_{2} \mathrm{~N}\right.$ pyrrolidine), $52.2\left(\mathrm{CH}_{2} \mathrm{CH}_{2} \mathrm{NH}\right), 45.2\left(\mathrm{CH}_{2} \mathrm{NH}\right), 48.0\left(\mathrm{CH}_{2} \mathrm{CO}\right), 171.0(\mathrm{CO}), 10.1$

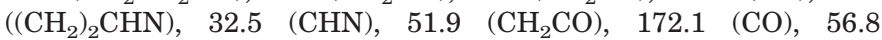
$\left(\mathrm{CH}_{3} \mathrm{CHCH}_{2} \mathrm{CH}_{3}\right), 29.4\left(\mathrm{CH}_{3} \mathrm{CHCH}_{2} \mathrm{CH}_{3}\right), 12.5\left(\mathrm{CH}_{3} \mathrm{CHCH}_{2} \mathrm{CH}_{3}\right)$, $19.8\left(\mathrm{CH}_{3} \mathrm{CHCH}_{2} \mathrm{CH}_{3}\right), 46.0\left(\mathrm{CH}_{2} \mathrm{CO}\right), 176.0$ (CO). HRMS: MS Calculated for $\mathrm{C}_{19} \mathrm{H}_{36} \mathrm{~N}_{5} \mathrm{O}_{3} 382.281815$. Found: 382.282518 .

6110. ${ }^{1} \mathrm{H}-\mathrm{NMR}\left(500 \mathrm{MHz}, 10^{\circ} \mathrm{C}\right.$ in $\mathrm{D}_{2} \mathrm{O}$, mixture of conformers), $\delta$ from N-terminal to C-terminal: 2.01-2.17 (m, $4 \mathrm{H}, \mathrm{CH}_{2} \mathrm{CH}_{2} \mathrm{~N}$ pyrrolidine), $3.11-3.72\left(\mathrm{~m}, 4 \mathrm{H}, \mathrm{CH}_{2} \mathrm{~N}\right.$ pyrrolidine), $3.59(\mathrm{t}, 2 \mathrm{H}$, $\mathrm{CH}_{2} \mathrm{CH}_{2} \mathrm{NH}$ ), 3.50 (t, $\left.2 \mathrm{H}, \mathrm{CH}_{2} \mathrm{NH}\right), 4.31$ and $4.38\left(\mathrm{~s}, 2 \mathrm{H}, \mathrm{CH}_{2} \mathrm{CO}\right)$, 2.67 and $2.80(\mathrm{~m}, 1 \mathrm{H}, \mathrm{CHN}), 0.58-0.92\left(\mathrm{~m}, 4 \mathrm{H},\left(\mathrm{CH}_{2}\right)_{2} \mathrm{CHN}\right), 3.88$ and $4.22\left(\mathrm{~s}, 2 \mathrm{H}, \mathrm{CH}_{2} \mathrm{CO}\right), 7.30-7.42(\mathrm{~m}, 5 \mathrm{H}, \mathrm{H}$ Arom $), 2.95-2.84(\mathrm{~m}$, $\left.2 \mathrm{H}, \mathrm{CH}_{2} \mathrm{CH}_{2} \mathrm{NH}\right), 3.59-3.67\left(\mathrm{~m}, 2 \mathrm{H}, \mathrm{CH}_{2} \mathrm{~N}\right), 4.05\left(\mathrm{~s}, 2 \mathrm{H}, \mathrm{CH}_{2} \mathrm{CO}\right)$. ${ }^{13} \mathrm{C}-\mathrm{NMR}\left(500 \mathrm{MHz}, 10^{\circ} \mathrm{C}\right.$ in $\left.\mathrm{D}_{2} 0\right), \delta$ from $\mathrm{N}$-terminal to C-terminal: $21.7\left(\mathrm{CH}_{2} \mathrm{CH}_{2} \mathrm{~N}\right), 54.0\left(\mathrm{CH}_{2} \mathrm{~N}\right), 48.8\left(\mathrm{CH}_{2} \mathrm{CH}_{2} \mathrm{NH}\right), 41.9\left(\mathrm{CH}_{2} \mathrm{NH}\right)$, $48.0\left(\mathrm{CH}_{2} \mathrm{CO}\right), 167.8(\mathrm{CO}), 7.0\left(\left(\mathrm{CH}_{2}\right)_{2} \mathrm{CHN}\right), 29.4(\mathrm{CHN}), 48.3$ and $48.4\left(\mathrm{CH}_{2} \mathrm{CO}\right), 169.1$ and $169.0(\mathrm{CO}), 49.4\left(\mathrm{CH}_{2} \mathrm{CH}_{2} \mathrm{~N}\right), 32.6\left(\mathrm{CH}_{2} \mathrm{~N}\right)$, 137.3 (C arom), 128.3 (CH orto arom), 128.2 (CH meta arom), 126.3 


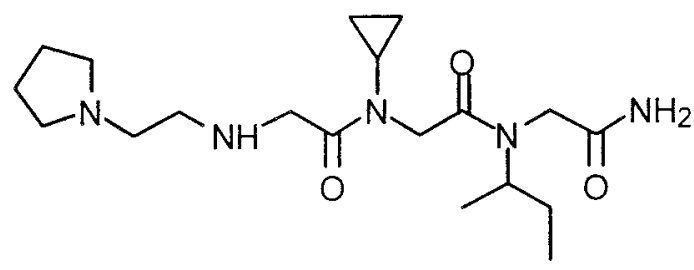

612

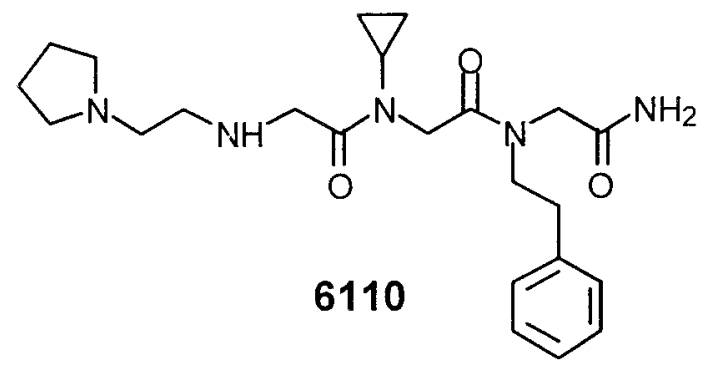

6110

Fig. 2. Structures of 6-1-2 and 6-1-10, two representative neuroprotective agents derived from the library of $N$-alkylglycine trimers.

(CH para arom), $47.9\left(\mathrm{CH}_{2} \mathrm{CO}\right), 172.1$ (CO). HRMS: MS calculated for $\mathrm{C}_{23} \mathrm{H}_{36} \mathrm{~N}_{5} \mathrm{O}_{3} 430.281815$. Found: 430.283409 .

\section{Primary Cultures of Neurons}

Primary cultures of cerebellar neurons were prepared using cerebella from 7- to 8-day-old Wistar rats as described (Miñana et al., 1998). Neurons were grown at $37^{\circ} \mathrm{C}$ in $5 \% \mathrm{CO}_{2}$ atmosphere. To prevent proliferation of non-neuronal cells, $10 \mu \mathrm{M}$ cytosine arabinoside was added $24 \mathrm{~h}$ after plating. Glucose, $5.6 \mathrm{mM}$ final concentration, was added to the culture medium twice a week.

\section{Assay of Protection against Glutamate Neurotoxicity}

Glutamate toxicity in cerebellar neurons was assayed after 11 to 15 days of culture. Briefly, culture medium was removed and kept at $37^{\circ} \mathrm{C}$ (conditioned medium). Cells were washed and incubated at $37^{\circ} \mathrm{C}$ for 20 min with $\mathrm{Mg}^{2+}$-free Locke's solution (154 mM NaCl, 5.6 $\mathrm{mM} \mathrm{KCl}, 3.6 \mathrm{mM} \mathrm{NaHCO}, 2.3 \mathrm{mM} \mathrm{CaCl}_{2}, 5.6 \mathrm{mM}$ glucose, $5 \mathrm{mM}$ HEPES, pH 7.4), containing $10 \mu \mathrm{M}$ glycine. Thereafter, this solution was removed and cells were incubated with $1 \mathrm{mM}$ glutamate in $\mathrm{Mg}^{2+}$-free Locke's solution without glycine at $37^{\circ} \mathrm{C}$ for $4 \mathrm{~h}$. Preincubation with glycine was convenient to obtain more reproducible results when comparing different culture preparations. Individual peptoids were added 20 min before glutamate addition. Cells were washed with $\mathrm{Mg}^{2+}$-free Locke's solution and the conditioned medium previously removed was added again. Cell viability was measured $24 \mathrm{~h}$ later by staining with fluorescein diacetate and propidium iodide as previously described (Felipo et al., 1993). The percentage of surviving neurons was calculated by assessing the ratio of fluorescein diacetate/propidium iodide (green/red) staining directly under the microscope. At least 1200 cells were counted for each data point.

\section{Determination of cGMP in Cultured Neurons}

Neurons were used 11 to 15 days after seeding. Monolayers were washed three times with prewarmed $\mathrm{Mg}^{2+}$-free Locke's solution. The assay of NMDA-induced formation of cGMP was carried out in the same medium. Treatments with $1 \mathrm{mM}$ NMDA were at $37^{\circ} \mathrm{C}$ for 5 min. cGMP was determined using the BIOTRAK cGMP enzyme immunoassay kit from Amersham plc as described (Montoliu et al., 1999). For each experiment, samples were measured in duplicate.

\section{Determination of Free Intracellular Calcium}

Changes in intracellular free $\mathrm{Ca}^{2+}$ were monitored in single neurons using an ACAS 570 confocal laser cytometer (Meridians Instruments, Okemos, MI). Primary cultures of cerebellar neurons were plated on 35-mm tissue culture dishes and loaded with $20 \mu \mathrm{M}$ Fluo$3 / \mathrm{AM}$ in the culture medium at $37^{\circ} \mathrm{C}$ for $1 \mathrm{~h}$. Thereafter, the cells were washed twice with prewarmed $\mathrm{Mg}^{2+}$-free Locke's solution, and $1 \mathrm{ml}$ of the same solution was added. To study the effects of the peptoids on free intracellular $\mathrm{Ca}^{2+}$ levels, each peptoid was added to the medium, the fluorescence was recorded for the time desired, and $250 \mu \mathrm{M}$ glutamate or NMDA was then added. $\mathrm{Ca}^{2+}$ levels were monitored continuously. Free intracellular calcium was quantified using the confocal laser cytometer as previously described (Marcaida et al., 1995a). Each experiment was repeated at least four times with three different neuronal cultures.

\section{Prevention of Ammonia-Induced, NMDA Receptor- Mediated Death of Mice}

Acute ammonia intoxication leads to excessive activation of NMDA receptors in brain (Hermenegildo et al., 2000), which is responsible for ammonia-induced death of animals (Marcaida et al., 1992; Hermenegildo et al., 1996). Male Swiss mice (25-35 g) were injected i.p. with $14 \mathrm{mmol} / \mathrm{kg}(3 \mu \mathrm{l} / \mathrm{g})$ of ammonium acetate. To assess the protective effect of peptoids, these were injected i.p. $10 \mathrm{~min}$ before ammonium injection. The number of mice surviving $24 \mathrm{~h}$ after injection was counted.

\section{Transient Bilateral Hemispheric Ischemia: Surgery and Treatments with Peptoids}

For the transient forebrain ischemia experiments, we used the four-vessel occlusion model of Pulsinelli and Brierley (1979) with the modifications of Schmidt-Kastner et al. (1989). Briefly, rats were anesthetized with $120 \mu \mathrm{g} / \mathrm{g}$ ketamine and $15 \mu \mathrm{g} / \mathrm{g}$ xylazine and placed in a rat holder. Vertebral arteries were coagulated permanently at the level of the lateral vertebral foramen with the aid of an electrocauter device. After $24 \mathrm{~h}$, we clamped temporarily (15 min) the two common carotids under halothane anesthesia. Rats received i.p. injections of the peptoids $(50 \mu \mathrm{g} / \mathrm{g} ; 2.5 \mu \mathrm{l} / \mathrm{g}$ ) three times: $15 \mathrm{~min}$ before occlusion of the carotids, immediately after removal of the carotid clamp, and at $24 \mathrm{~h}$ of reperfusion. After a 7-day survival period, rats were deeply anesthetized with sodium pentobarbital and perfused transcardially with $0.9 \%$ saline followed by $4 \%$ paraformaldehyde in phosphate buffer $\left(0.1 \mathrm{M} \mathrm{NaKPO}_{4}\right)$. The brains were removed and stored in $30 \%$ sucrose in phosphate buffer until further processing.

\section{Detection of Neurodegeneration by Silver Impregnation}

For the detection of neuronal somata, axons, and terminals undergoing degeneration, free-floating $50-\mu \mathrm{m}$-thick sagittal sections were stained with a silver impregnation protocol (FD NeuroSilver kit I; FD Neurotechnologies, Baltimore, MD) (Gallyas et al., 1992; Beltramino et al., 1993). Degenerating neurons and axons appeared stained black against a background of relatively spared neural processes stained yellow/brown (Fig. 7).

\section{Detection of Neurons Showing Activated Caspase-3}

Free-floating $25-\mu \mathrm{m}$-thick sagittal sections of the same brains were treated with standard single-antigen immunohistochemical methods. Sections were exposed to hydrogen peroxide, blocked, and incubated overnight with antiserum raised against the large fragment of activated caspase-3, resulting from cleavage after aspartic acid at position 175 (1:100; Cell Signaling Technology Inc., Beverly, MA). Sections were then incubated with biotinylated secondary antiserum and with the avidin-biotin complex (ABC kit; Vector Laboratories, Burlingame, CA). The horseradish peroxidase reaction products were visualized with diaminobenzidine and intensified with nickel sulfate, appearing as discrete black precipitates (Fig. 8). 


\section{Quantification}

For the sections stained with the silver impregnation method, we estimated the area in the dorsal striatum showing dense silver precipitates. Between three and five sections were averaged per animal. For the sections processed for immunohistochemistry, caspase-3-positive cells were counted within a rectangular area of ca. $1.5 \mathrm{~mm}^{2}$ at the level of the dorsal striatum, caudally (Fig. 7). At least four adjacent sections were averaged per animal. Estimations of ischemic injury as measured by the silver method and counts for active caspase- 3 immunoreactivity were carried out blind to the experimental treatments.

\section{Statistics}

Results of Figs. 3, 4, and 6 were analyzed by one-way analysis of variance followed by post hoc Dunnett's test or Student's $t$ test using the PRISM program (version 2.0; GraphPad Software, San Diego, CA) and the results of Fig. 8 were analyzed by Tukey-Kramer test.

All animal experiments were carried out in accordance to the European Union Guidelines for Care and Use of Laboratory Animals. All efforts were made to minimize animal suffering.

\section{Results}

Identification of Novel Neuroprotectant Molecules from a Library of Trialkylglycines. A positional scanning, mixture-based combinatorial library composed of trimers of $N$-alkylglycines was screened to identify molecules that prevent glutamate-induced neuronal death in primary cultures of cerebellar neurons. The design of this library contained two distinctive features. First, the use of the positional scanning format strategy for its construction. Second, the selection of the diversity included the use primary amines bearing an additional tertiary amino moiety. The introduction of these amines conducted to trimers containing additional protonable fragments, which could complement the activity pattern and bioavailability of the library members. The general structure of the trimers is shown in Fig. 1. The library was organized in 66 mixtures, each containing 484 molecules, giving rise to a chemical diversity of 10,648 individual trialkylglycines. Screening of the 66 mixtures

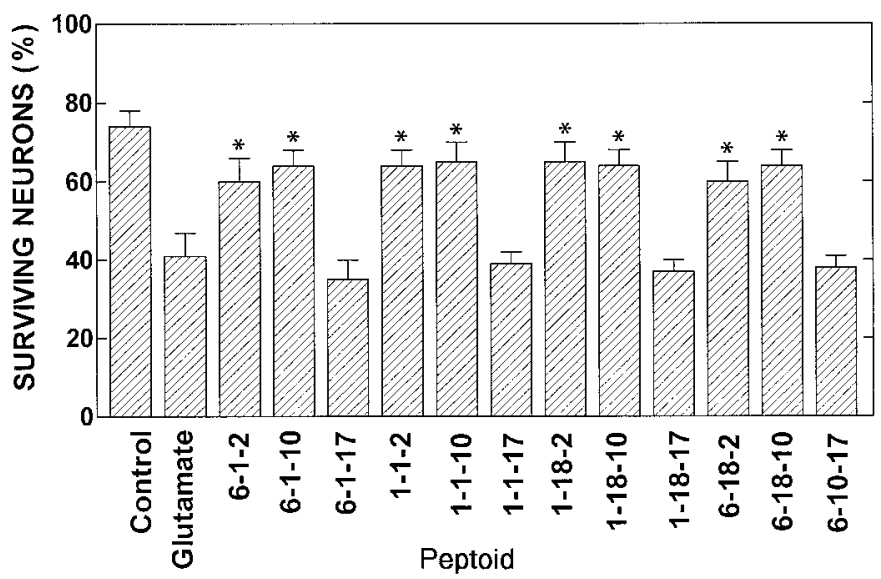

Fig. 3. Protective effect of peptoids against glutamate neurotoxicity in primary cultures of cerebellar neurons. Primary cultures of cerebellar neurons were used 10 to 14 days after seeding. Neurons were treated with $1 \mathrm{mM}$ glutamate after preincubation for $15 \mathrm{~min}$ with $50 \mu \mathrm{g} / \mathrm{ml}$ of the indicated peptoids. Neuronal viability was determined as indicated under Experimental Procedures. At least 1200 cells/point were counted in each assay. Values are the mean \pm standard deviations of six assays using five different cultures. Values that are significantly different from controls $(p<0.001)$ are indicated by asterisks. identified the preferred diversity at the three separate positions $\left(R_{1}, R_{2}\right.$, and $R_{3}$ ) of the oligomer (Fig. 1). At the $R_{1}$ position the selected amines were cyclopropyl (denoted as amine 1) and 2-N-pyrrolidinyl (denoted as amine 6); at the $\mathrm{R}_{2}$ position were cyclopropyl and 2 -( $N$-morpholino)ethyl (denoted as amine 18); and at the $R_{3}$ position were sec-butyl (denoted as amine 2), 2-phenylethyl (amine 10), and 2,4-(aminosulphonylphenyl)ethyl (amine 17).

When used in concert, these results suggest the chemical identity of potential neuroprotectant molecules. Hence, we synthesized a family of the individual peptoids containing the different combinations of the above-mentioned amines and assayed their activity preventing glutamate-induced neuronal death. The structures of two of these compounds are shown in Fig. 2. As illustrated in Fig. 3, several of these peptoids exhibited remarkable neuroprotective activity at 50 $\mu \mathrm{g} / \mathrm{ml}(\approx 100 \mu \mathrm{M})$.

Because most of the active peptoid exhibit a similar neuroprotective efficacy, further characterization was focused on two of these peptoids, 6-1-2 and 6-1-10. These compounds were purified and rigorously characterized by analytical and spectroscopic means.

Dose-response studies showed that concentrations as low as $1 \mu \mathrm{g} / \mathrm{ml}(\approx 2 \mu \mathrm{M})$ prevented $20 \%$ neuronal culture neurodegeneration. The effect was maximal at $50 \mu \mathrm{g} / \mathrm{ml}(\approx 100 \mu \mathrm{M})$ with a 70\% neuroprotection (Fig. 4A). For compound 6-1-2 the $\mathrm{IC}_{50}$ (concentration of peptoid that prevented half of maximal neurodegeneration) was $\approx 8 \mu \mathrm{M}$ and for $6-1-10$ was $\approx 15 \mu \mathrm{M}$. Therefore, these newly identified trialkylglycinebased molecules are potent neuroprotectants.

Trialkylglycine-Based Neuroprotectants Do Not Inhibit Activation of NMDA Receptor. To gain insights on the mechanism underlying the neuroprotective activity of these trialkylglycines, we investigated whether they act as antagonists of NMDA receptors. We determined whether these peptoids reduced the raise in intracellular $\mathrm{Ca}^{2+}$ induced by activation of NMDA receptor by L-glutamate or

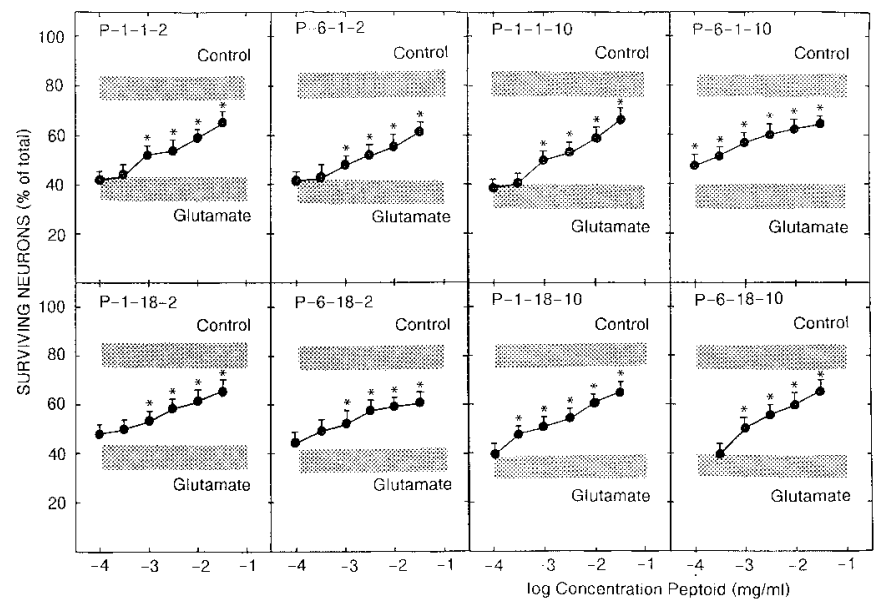

Fig. 4. Concentration dependence of the protective effect of peptoids on glutamate neurotoxicity in primary cultures of cerebellar neurons. Primary cultures of cerebellar neurons were used 10 to 14 days after seeding. Neurons were treated with $1 \mathrm{mM}$ glutamate after preincubation for 15 min with the indicated concentrations of the different peptoids and cell viability was determined as indicated under Experimental Procedures. At least 1200 cells/point were counted in each assay. Values are the mean \pm standard deviations of five to six assays using four to six different cultures. Values that are significantly different from controls $(p<0.001)$ are indicated by asterisks. 
NMDA. As depicted in Fig. 5, the NMDA receptor-mediated increase in intracellular $\mathrm{Ca}^{2+}$ was not significantly altered by addition of compounds 6-1-2 and 6-1-10 to the extracellular medium before and during treatment with the agonist. The lack of inhibitory effect was independent of the agonist used because similar results were obtained with glutamate or NMDA. In contrast, addition of MK-801 drastically prevented $\mathrm{Ca}^{2+}$ influx (Fig. 5). Consistent with this notion, both peptoids did not significantly block the glutamate-evoked ionic currents from recombinant rat brain NMDA receptors heterologously expressed in Xenopus oocytes ( $25 \pm 5 \%$ at 50 $\mu \mathrm{M}$; data not shown). These findings imply that these peptoids do not inhibit NMDA receptor activity.

Trialkylglycines Do Not Alter Glutamate-Induced cGMP Production in Neurons. Activation of the NMDA receptor leads to production of cGMP through the glutamatenitric oxide-cGMP pathway. It has been shown that inhibition of this signaling pathway prevents glutamate neurotoxicity (Dawson et al., 1991; Lafon-Cazal et al., 1993; Marcaida et al., 1995b) and that inhibition of glutamate-induced for- mation of cGMP by using inhibitors of soluble guanylate cyclase prevents glutamate-induced neuronal death in cerebellar neurons in culture (Hermenegildo et al., 1998; Montoliu et al., 1999). To assess whether the protective peptoids interfere with any step of this pathway, we next investigated whether identified trialkylglycines decreased the production of cGMP in cultured cerebellar neurons treated with NMDA. As shown in Fig. 6, none of the peptoids affected the NMDAinduced production of cGMP. Therefore, the neuroprotective activity exerted by these molecules is not due to inhibition of any of the steps of this signaling pathway.

Trialkylglycines Prevent Ammonia-Induced, NMDA Receptor-Mediated Death of Mice. To assess the protective activity of identified peptoids in vivo, we next investigated whether compounds 6-1-2 and 6-1-10 were able to prevent death in an animal model of glutamate-mediated neurotoxicity. Intraperitoneal administration of high doses of ammonium acetate leads to animal death. Ammonia lethality is mediated by excessive activation of NMDA receptors (Hermenegildo et al., 1996, 2000). We used this model to evaluate
A

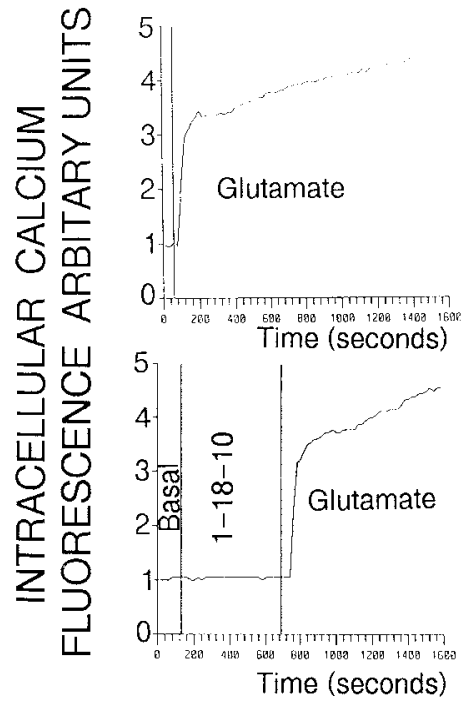

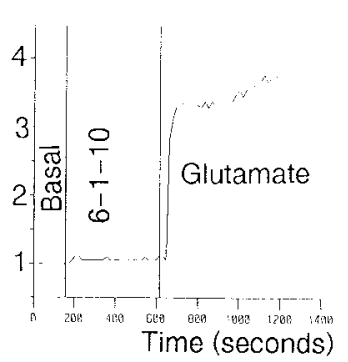

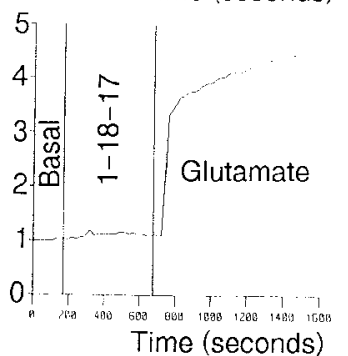

B

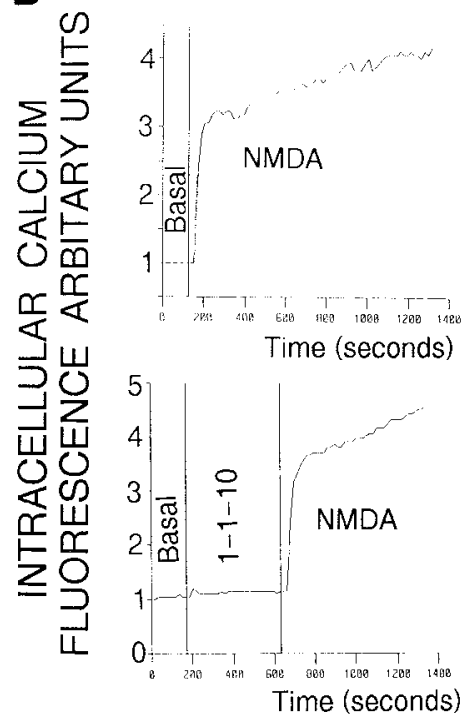

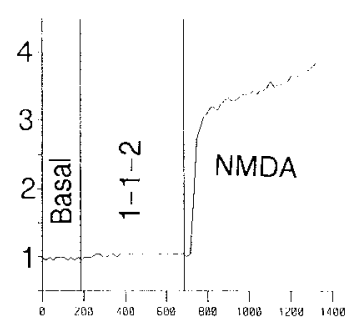

Time (seconds)

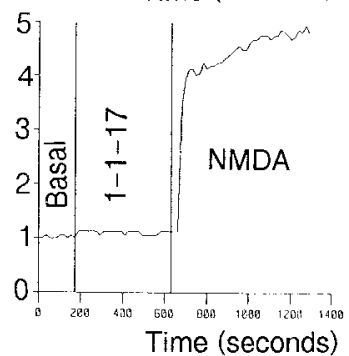

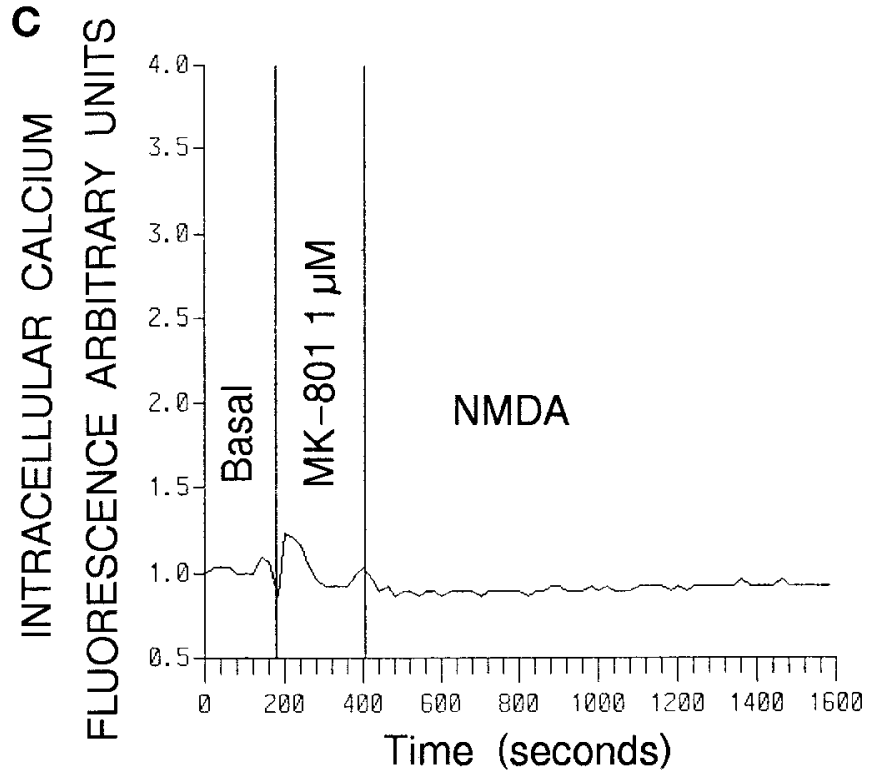

Fig. 5. Peptoids do not prevent glutamate- or NMDA-induced increase in free intracellular $\mathrm{Ca}^{2+}$ in neurons. Primary cultures of cerebellar neurons were prepared using 35 -mm-diameter tissue culture dishes and were used 10 to 14 days after seeding. Free intracellular calcium content was determined with fluo-3/AM using a confocal microscope. For controls the basal calcium level was recorded for $200 \mathrm{~s}$, then the agonist $(250 \mathrm{pM}$ NMDA or glutamate) was added (indicated by vertical line), and the fluorescence was recorded for the indicated time. For assaying the effect of peptoids or MK-801 the basal calcium level was recorded for $200 \mathrm{~s}$. Peptoid (50 pg/ml) or MK-801 ( $1 \mu \mathrm{M})$ was then added (first vertical line), and the fluorescence was recorded for $600 \mathrm{~s}$, followed by addition of the agonist (second vertical line). 


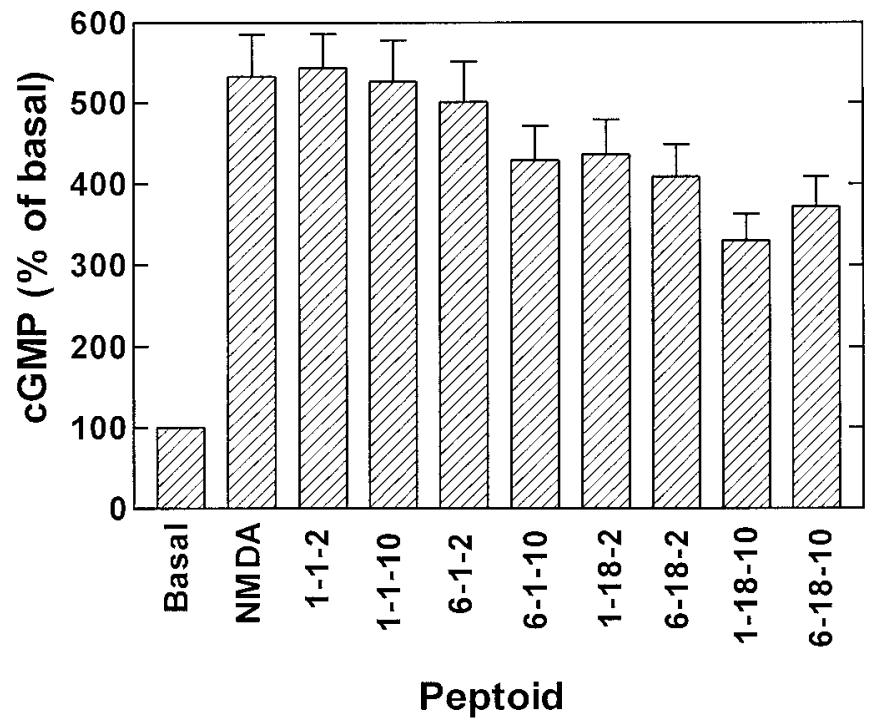

Fig. 6. Effects of peptoids on NMDA-induced formation of cGMP in neurons. Neuronal cultures were used 10 to 14 days after seeding. Cells were washed in $\mathrm{Mg}^{2+}$-free Locke's solution and preincubated with the same solution for 20 $\min$ at $37^{\circ} \mathrm{C}$. Then $50 \mu \mathrm{g} / \mathrm{ml}$ of the indicated peptoids were added and incubated for $15 \mathrm{~min}$ before addition of NMDA ( $1 \mathrm{mM}$ final concentration). Basal and NMDA-induced formation of cGMP were measured as indicated under Experimental Procedures. For each experiment, the basal level of formation cGMP in control neurons was considered as 100\%. Values are the mean \pm standard deviations of duplicate samples from five experiments using four different cultures. All values with NMDA alone NMDA + peptoid are significantly different $(p<0.001)$ from basal.

the in vivo protective activity of trialkylglycines 6-1-2 and 6-1-10 (Table 1). Notably, intraperitoneal injection of $50 \mu \mathrm{g} / \mathrm{g}$ peptoid 6-1-2, 10 min before injection of ammonia, afforded a
TABLE 1

Peptoids 6-1-2 and 6-1-10 prevent ammonia-induced, NMDA receptormediated death of mice

Male Swiss mice weighing 25 to $35 \mathrm{~g}$ were used. Peptoids were injected intraperitoneally $10 \mathrm{~min}$ before ammonium injection. Ammonium acetate $(14 \mathrm{mmol} / \mathrm{kg}$ ) was also injected intraperitoneally. The concentrations of the solutions were adjusted to reach the desired dose by injecting $3 \mu \mathrm{l}$ per gram of body weight. The number of surviving mice was counted $24 \mathrm{~h}$ after ammonium injection. All animals surviving at this time remained alive for several weeks until they were sacrificed.

\begin{tabular}{ccc}
\hline Compound Injected & $\begin{array}{c}\text { Number of Mice } \\
\text { Surviving/Injected }\end{array}$ & Survival \\
\hline & & $\%$ total \\
None & $5 / 30$ & 16 \\
$6-1-10$ & $24 / 29$ & 82 \\
$6-1-2$ & $24 / 24$ & 100 \\
\hline
\end{tabular}

complete protection against ammonia-induced death of mice (24 of 24 mice survived to ammonia intoxication), whereas only $16 \%$ of mice injected with saline survived. Similarly, treatment with $50 \mu \mathrm{g} / \mathrm{g}$ peptoid $6-1-10$ protected $82 \%$ of mice. These results are comparable to those reported for NMDA receptor antagonists (Hermenegildo et al., 1996, 2000). Thus, identified peptoids exhibit in vivo neuroprotectant activity.

Trialkylglycines Prevent Ischemic Neurodegeneration in Rats. To further characterize the in vivo activity of these peptoids, we evaluated their beneficial effect in preventing the neuronal damage provoked by cerebral ischemia. For these experiments, peptoids ( $50 \mu \mathrm{g} / \mathrm{g}$ ) were administered to rats 15 min before provoking the ischemic insult, as well as 1 and $24 \mathrm{~h}$ after the ischemia onset. Animals were sacrificed 7 days later and the extent of brain damage was evaluated. As shown in Fig. 7, the ischemic insult provoked by transient occlusion of the carotids produced extensive degeneration in the dorsal and caudal aspects of the caudoputamen, mainly
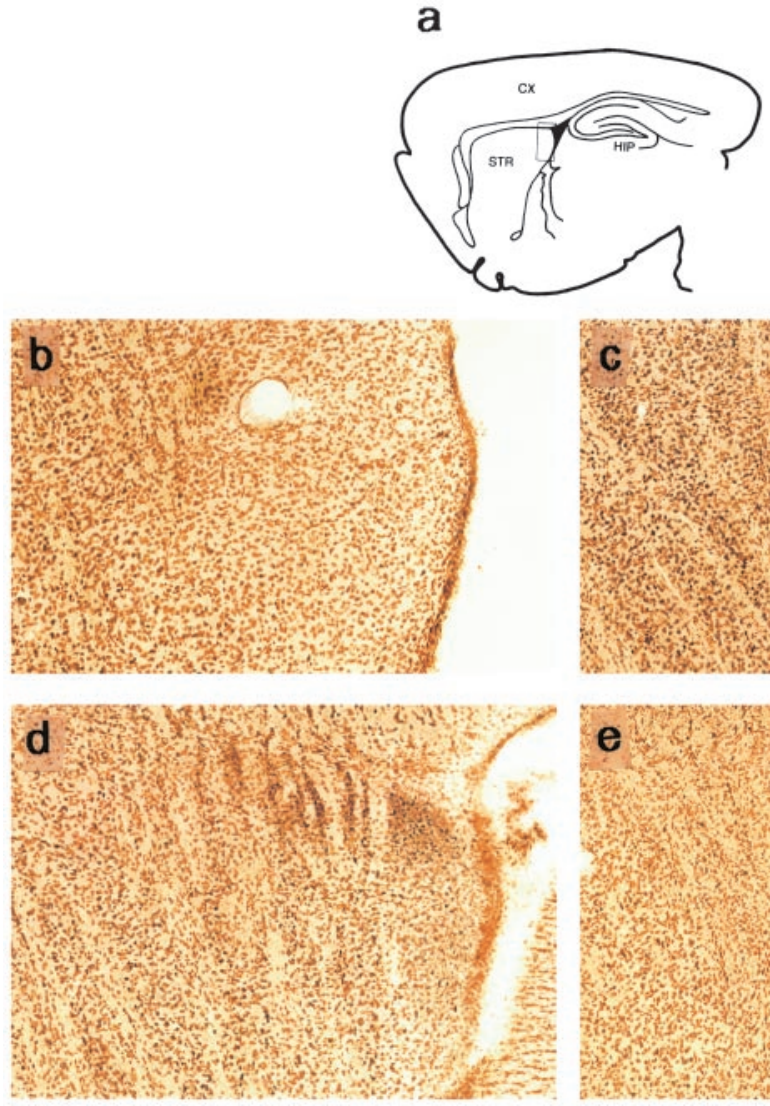

Fig. 7. Peptoids 6-1-2 and 6-1-10 prevent neurodegeneration induced in striatum by ischemia. Rats were subjected to transient ischemia, with or without treatment with peptoids 6-1-2 or 6-1-10 as described under Experimental Procedures. Degeneration neurons were visualized by the silver impregnation method and given the dark staining shown in c. a, diagram representing the rectangular area of the caudoputamen considered for quantification purposes. b, control rat. c, rat subjected to ischemia without treatments. $\mathrm{d}$, rat treated with peptoid 6-1-10 and subjected to ischemia. e, rat treated with peptoid 6-1-2 and subjected to ischemia. Similar results were obtained in two different rats per group. CX, cerebral cortex; STR, striatum; HIP, hippocampus. 
in the immediate environs of the lateral ventricle. In animals exposed to transient ischemia, areas of dark silver stain extended rostrally in the lateral, sensorimotor area of the caudoputamen. The administration of the peptoids notably prevented the neuronal damage provoked by ischemia, as revealed by the significant decrease in silver accumulation in the dorsal caudoputamen. Peptoid 6-1-10 reduced the estimated area of insult by $65 \%$ and peptoid $6-1-2$ by $82 \%$ (Fig. 7).

It has been reported that many neurons undergo apoptosis after ischemia (Choi and Rothman, 1990). We questioned whether selected peptoids may also attenuate ischemia-induced neuronal apoptosis. For this task, we monitored the content of activated caspase- 3 in the striatum of control and peptoid-treated rats that suffered an ischemic attack. As shown in Fig. 8, ischemia induced a significant activation of caspase-3 in control animals, reflecting induction of apoptosis in a large number of neurons. In marked contrast, animals treated with $50 \mu \mathrm{g} / \mathrm{g}$ i.p. peptoids exhibited a significant reduction in caspase- 3 activation in the same brain region. Noticeably, peptoid 6-1-2 decreased by $74 \%$ the number of apoptotic neurons, and peptoid $6-1-10$ by $50 \%$ (Fig. $8 \mathrm{E}$ ). Therefore, these trialkylglycines reduce the infarct volume after transient ischemia in rats.

\section{Discussion}

Neurodegeneration is a multifaceted process involving, among others, the unbalance of the glutamatergic system.
Prolonged exposure of neurons to moderate-to-high concentrations of L-glutamate irreversibly culminates in neuronal damage. It is generally accepted that the influx of $\mathrm{Ca}^{2+}$ as a result of excessive activation of the NMDA receptor underlies the toxic actions of glutamate in many systems. ( $S$ )- $\alpha$-Amino2,3-dyhydro-5-methyl-3-oxo-4-isoxazolepropanoic acid receptors also mediate glutamate neurotoxicity under certain conditions (Choi and Rothman, 1990; Lee and Choi, 1999). The pivotal role assigned to NMDA receptors in neurodegeneration has signaled this channel protein as prime target for neuroprotectant drug development. However, much of the initial enthusiasm has declined because of poor performance of NMDA receptor antagonists in clinical trials (Choi and Rothman, 1990; Garthwaite, 1995). Apparently, the clinical unsuitability of these compounds may arise, at least partially, from their psychotomimetic effects, especially for slowdeveloping neurodegeneration (Choi and Rothman, 1990; Chase and Oh, 2000). Moreover, it has been reported that NMDA antagonists may enhance neuronal death in vivo (Ikonomidou et al., 1999; Olney et al., 2000). Accordingly, new therapeutic approaches that attenuate excitotoxicity should be evaluated and developed. To pursue this goal, we used a neuroprotection-based cellular assay suitable to screen combinatorial libraries composed either of mixtures or of individual compounds. At variance with target-directed screenings, our assay directly evaluates the efficiency of molecules attenuating glutamate-induced neuronal death. A sa-
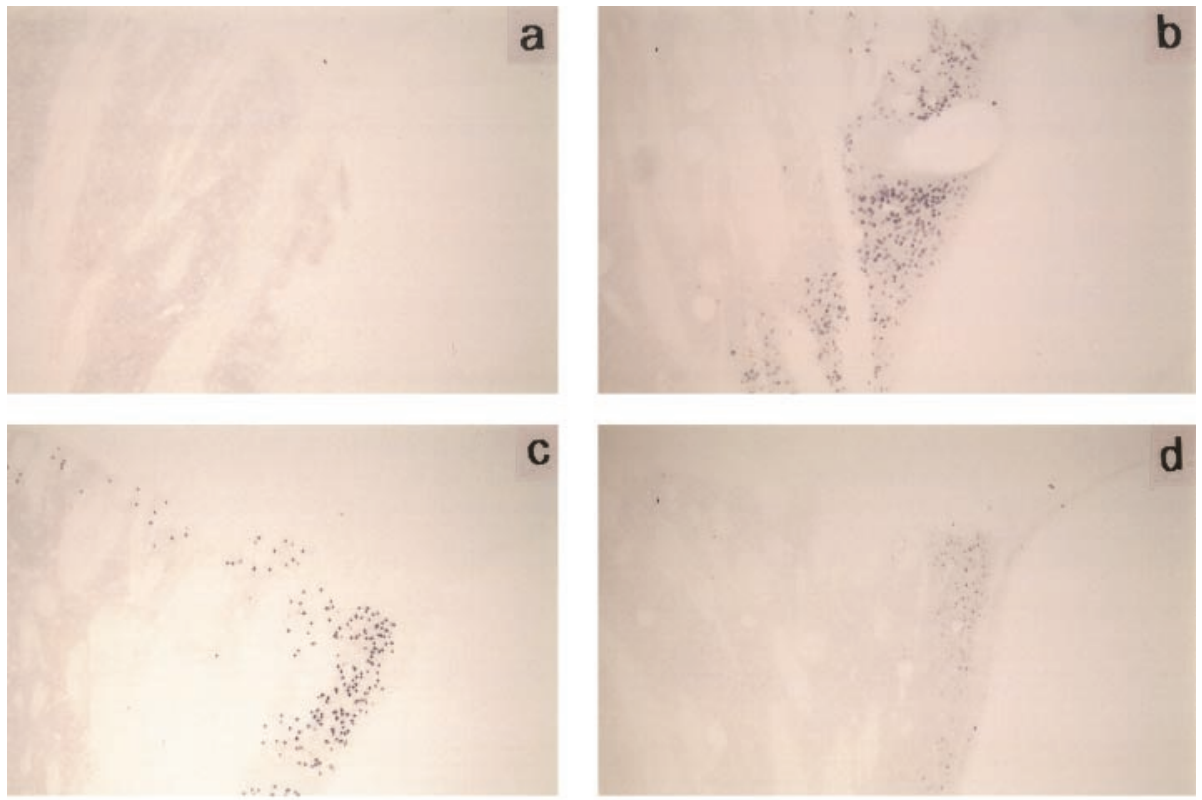

e

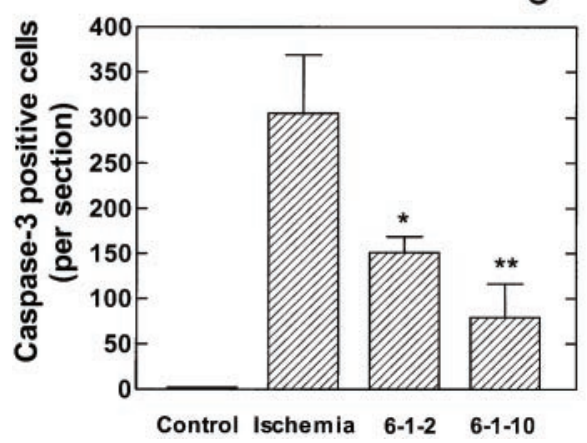

Fig. 8. Peptoids 6-1-2 and 6-1-10 prevent activation of caspase-3 induced in striatum by ischemia. Rats were subjected to transient ischemia, with or without treatment with peptoids 6-1-2 or 6-1-10 as described under Experimental Procedures. Distribution of activated caspase-3 in parasagittal sections of the caudoputamen after ischemia treatments was detected using a specific antibody as described under Experimental Procedures. a, control rat. b, rat subjected to ischemia without treatments. c, rat treated with peptoid 6-1-10 and subjected to ischemia. d, rat treated with peptoid 6-1-2 and subjected to ischemia. Similar results were obtained in two different rats per group. e, inhibition of ischemia-induced expression of caspase- 3 by peptoid treatments. Analysis of variance showed a significant effect of treatment $[F(3,9)=12.976, p<0.001] . *, p<0.05 ; * *$, $p<0.01$ (Tukey-Kramer test). 
lient application of this cellular assay is the identification of a novel class of trialkylglycine-based neuroprotectant molecules that significantly prevents excitotoxic neuronal death in in vitro and in vivo models of neurodegeneration. Oligomers of $\mathrm{N}$-substituted glycines provide a class of small, non-natural molecules that are proteolytically stable and have potent biological activities (Ostergaard and Holm, 1997). A major advantage of using short oligomers is that they usually display acceptable tissue penetration properties and better pharmacological conformities (Lipinski et al., 1997; Newton, 1999).

Two peptoids, 6-1-2 and 6-1-10, protected primary neuronal cultures against the deleterious glutamate neurotoxicity with efficiencies that rival those characteristics of NMDA receptor antagonists. Of significance, both peptoids at 50 $\mu \mathrm{g} / \mathrm{g}$ displayed remarkable neuroprotective activity in two in vivo models of acute excitotoxicity, namely, acute ammonia intoxication and transient ischemia. Thus, these novel peptoids may be considered leads for drug development.

The neuroprotective activity exerted by these peptoids does not appear to be mediated by blockade of the NMDA receptor or by attenuation of glutamate/NMDA-induced $\mathrm{Ca}^{2+}$ influx. These observations suggest that newly identified molecules may interfere with signaling steps downstream in the glutamate-nitric oxide-cGMP cascade. However, our data demonstrate that trialkylglycines did not alter glutamate-induced neuronal cGMP synthesis, thus ruling out inhibition of nitricoxide synthase or guanylate cyclase. Furthermore, we have also observed that neither of these compounds inhibit the enzymatic activity of caspase-3 (data not shown). The question that arises is, What is the molecular mechanism underlying the neuroprotective activity of selected peptoids? Our studies show that these peptoids prevent neuronal death without attenuating glutamate-mediated neuronal $\mathrm{Ca}^{2+}$ overload. Additional studies are required to unequivocally uncover the molecular entity targeted by these compounds.

The development of this new class of neuroprotectant molecules may provide novel therapies for the treatment of disorders involving excessive activation of glutamate receptors such as neuronal damage in ischemia and several neurodegenerative and psychiatric disorders. Because these molecules do not block the NMDA receptor they may not exhibit the unwanted side effects that appear after chronic administration of NMDA receptor antagonists. Furthermore, because these peptoids appear to block ischemia-induced apoptosis they might be also useful in a therapeutic approach directed to dual inhibition of excitotoxic necrosis and apoptosis (Lee and Choi, 1999).

\section{References}

Beltramino CA, de Olmos JS, Gallyas F, Heimer L, and Zaborszky L (1993) Silver staining as a tool for neurotoxic assessment. NIDA Res Monogr 136:101-125.

Bräuner-Osborne H, Egebjerg J, Nielsen E, Madsen U, and Krogsgaard-Larsen P

(2000) Ligands for glutamate receptors: design and therapeutic prospects. $J$ Med Chem 43:2609-2645.

Chase TN and Oh JD (2000) Striatal mechanisms and pathogenesis of parkinsonian signs and motor complications. Ann Neurol 47 (Suppl 1):122-129.

Chenard BL and Menniti FS (1999) Antagonists selective for NMDA receptors containing the NR2B subunit. Curr Pharmacol Des 5:381-404

Choi DW (1987) Ionic dependence of glutamate neurotoxicity. J Neurosci 7:369-379. Choi DW and Rothman SM (1990) The role of glutamate neurotoxicity in hypoxicischemic neuronal death. Annu Rev Neurosci 13:171-182.

Dawson VL, Dawson T, Bartley DA, Uhl GR, and Snyder SH (1993) Mechanisms of nitric oxide-mediated neurotoxicity in primary brain cultures. $J$ Neurosci 13:26512661.

Dawson VL, Dawson T, London ED, Bredt DS, and Snyder SH (1991) Nitric oxide mediates glutamate neurotoxicity in primary cortical cultures. Proc Natl Acad Sci USA 88:6368-6371.
During MJ, Symes CW, Lawlor PA, Lin J, Dunning J, Fitzsimons HL, Poulsen D, Leone P, Xu R, Dicker BL, Lipski J, and Young D (2000) An oral vaccine against NMDAR1 with efficacy in experimental stroke and epilepsy. Science (Wash DC) 287:1453-1460.

Felipo V, Miñana MD, and Grisolía S (1993) Inhibitors of protein kinase C prevent the toxicity of glutamate in primary neuronal cultures. Brain Res 604:192-196.

Ferrer-Montiel AV, Merino JM, Blondelle SE, Pérez-Payá E, Houghten RA, and Montal M (1998) Selected peptides targeted to the NMDA receptor channel protect neurons from excitotoxic death. Nat Biotech 16:286-291.

Figliozzi GM, Goldsmith R, Ng SC, Banville SC, and Zuckermann RN (1996) Synthesis of $N$-substituted glycine peptoid libraries. Methods Enzymol 267:437-447. Gallyas F, Zoltay G, and Dames W (1992) Formation of "dark" (argyrophilic) neurons of various origin proceeds with a common mechanism of biophysical nature (a novel hypothesis). Acta Neuropathol 83:504-509.

Garthwaite J (1995) NMDA receptors, neuronal development, and neurodegeneration, in The NMDA Receptor (Collingridge GL ed) pp 428-457, Oxford University Press, Oxford.

Hermenegildo C, Marcaida G, Montoliu C, Grisolía S, Miñana MD, and Felipo V (1996) NMDA receptor antagonists prevent acute ammonia toxicity in mice. Neurochem Res $21: 1237-1244$.

Hermenegildo C, Monfort P, and Felipo V (2000) Activation of $N$-methyl-D-aspartate receptors in rat brain in vivo following acute ammonia intoxication: characterization by in vivo brain microdialysis. Hepatology 31:709-715.

Hermenegildo C, Montoliu C, Llansola M, Muñoz MD, Gaztelu JM, Miñana MD, and Felipo V (1998) Chronic hyperammonemia impairs glutamate-nitric oxide-cyclic GMP pathway in cerebellar neurons in culture and in the rat in vivo. Eur $\mathrm{J} \mathrm{Neu-}$ rosci 10:3201-3209.

Ikonomidou C, Bosch F, Miksa M, Bittigau P, Vockler J, Dikranian K, Tenkova TI, Stefovska V, Turski L, and Olney JW (1999) Blockade of NMDA receptors and apoptotic neurodegeneration in the developing brain. Science (Wash DC) 283:7074.

Ikonomidou C, Stefovska V, and Turski L (2000) Neuronal death enhanced by $N$-methyl-D-aspartate antagonists. Proc Natl Acad Sci USA 97:12885-12890.

Kroemer G, Dallaporta B, and Reche-Rigon M (1998) The mitochondrial death/life regulator in apoptosis and necrosis. Annu Rev Physiol 60:619-642.

Lafon-Cazal M, Culcasi M, Gaven F, Pietri S, and Bockaert J (1993) Nitric oxide, superoxide and peroxynitrite: putative mediators of NMDA-induced cell death in cerebellar granule cells. Neuropharmacology 32:1259-1266

Lipinski CA, Lombardo F, Dominy BW, and Fenney PJ (1997) Experimental and computational approaches to estimate solubility and permeability in drug discovery and development settings. Adv Drug Deliv Res 23:3-25.

Lipton SA and Rosenburg PA (1994) Excitatory amino acids as a final common pathway for neurologic disorders. New Engl J Med 330:613-622.

Marcaida G, Felipo V, Hermenegildo C, Miñana MD, and Grisolía S (1992) Acute ammonia toxicity is mediated by NMDA type of glutamate receptors. FEBS Lett 296:67-68.

Marcaida G, Miñana MD, Burgal M, Grisolía S, and Felipo V (1995a) Ammonia prevents activation of NMDA receptors by glutamate in rat cerebellar neuronal cultures. Eur J Neurosci 7:2389-2395.

Marcaida G, Miñana MD, Grisolía S, and Felipo V (1995b) Lack of correlation between glutamate-induced depletion of ATP and neuronal death in primary cultures of cerebellum. Brain Res 695:146-150.

Mattson MP, Zhang Y, and Bose S (1993) Growth factors prevent mitochondrial dysfunction, loss of calcium homeostasis, and cell injury, but not ATP depletion in hippocampal neurons deprived of glucose. Exp Neurol 121:1-13

Miñana MD, Hermenegildo C, Llansola M, Montoliu C, Grisolía S, and Felipo V (1996) Carnitina and choline derivates containing a trimethylamine group prevent ammonia toxicity in mice and glutamate toxicity in primary cultures of neurons. J Pharmacol Exp Ther 279:194-199.

Miñana MD, Montoliu C, Llansola M, Grisolía S, and Felipo V (1998) Nicotine prevents glutamate-induced proteolysis of the microtubule-associated protein MAP-2 and glutamate neurotoxicity in primary cultures of cerebellar neurons. Neuropharmacology 37:847-857.

Montoliu C, Llansola M, Kosenko E, Corbalán R, and Felipo V (1999) Role of cyclic GMP in glutamate neurotoxicity in primary cultures of cerebellar neurons. Neuropharmacology 38:1883-1891.

Morris RGM, and Davis M (1995) The role of NMDA receptors in learning and memory, in The NMDA Receptor (Collingridge GL ed) pp 340-376, Oxford University Press, Oxford.

Newton CG (1999) Molecular diversity in drug design. Application to high-speed synthesis and high-throughput screening, in Molecular Diversity in Drug Design (Dean PM and Lewis, RA eds) pp 23-42, Kluwer Academic Press, New York.

Olney JW, Ishimaru MJ, Bittigau P, and Ikonomidou C (2000) Ethanol-induced apoptotic neurodegeneration in the developing brain. Apoptosis 5:515-521.

Ostergaard S and Holm A (1997) Peptomers: a versatile approach for the preparation of diverse combinatorial peptidomimetic bead libraries. Mol Divers 3:17-27.

Pinilla C, Appel JR, Blanc P, and Houghton RA (1992) Rapid identification of high affinity peptide ligands using positional scanning synthetic peptide combinatorial libraries. BioTechniques 13:901-902, 904-905.

Pulsinelli WA and Brierley J (1979) A new model of bilateral hemispheric ischemia in the unanesthetized rat. Stroke 10:256-272.

Schmidt-Kastner R, Paschen W, Ophoff BG, and Hossmann KA (1989) A modified four-vessel occlusion model for inducing incomplete forebrain ischemia in rats. Stroke 20:938-946.

Address correspondence to: Vicente Felipo, Laboratory of Neurobiology, Instituto de Investigaciones Citológicas, FVIB, Amadeo de Saboya 4, 46010 Valencia, Spain. E-mail: vfelipo@ochoa.fib.es 